\title{
Studi Model Distribusi Pencemaran di Pantai Utara Jawa Tengah Menggunakan Model MIKE 21 ECOLab
}

\author{
Adam Rus Nugroho', Rudhy Akhwady ${ }^{2}$, Dimas Metakaryanto ${ }^{3}$, Fahrul Yahya ${ }^{3}$ \\ ${ }^{1}$ Jurusan Teknik Lingkungan Universitas Islam Indonesia \\ Jl. Kaliurang Km.14,5 Yogyakarta 55584 \\ ${ }^{2}$ Kementerian Kelautan dan Perikanan \\ ${ }^{3}$ Institut Teknologi Sepuluh Nopember \\ E-mail: ${ }^{1}$ adam.rusn@uii.ac.id
}

\begin{abstract}
Central Java has several estuaries which highly populated in their area, generating high load of waste water discharge. Research conducted on two of the estuaries, Comal estuary in Pemalang and Garang estuary in Semarang. Waste water discharge from population around upstream river of Comal and Garang pollute both estuaries, which are in north coast of Central Java. The aim of this research is to determine the amount of pollutants which enter the estuary and become sediment in Comal and Garang river estuary. The amount of pollution has been analyzed by QUAL2Kw program which then the result would be input data for sediment analysis using MIKE 21 ECOLab program. The result of research state that Comal estuary has BOD concentration of $4.26 \mathrm{mg} / \mathrm{L}$ on west season and $4.21 \mathrm{mg} / \mathrm{L}$ on east season. While Garang estuary has BOD concentration of $18.21 \mathrm{mg} / \mathrm{L}$ on west season and $4.73 \mathrm{mg} / \mathrm{L}$ on east season.
\end{abstract}

Key words: estuary pollution model, MIKE 21 ECOLab, water pollution

\begin{abstract}
Abstrak
Provinsi Jawa Tengah memiliki beberapa muara sungai beberapa di antaranya adalah muara Comal di Pemalang dan muara Garang di Semarang. Kedua wilayah tersebut memiliki kepadatan penduduk yang tinggi sehingga buangan air limbah yang dihasilkan juga tinggi. Air limbah dari penduduk yang masih dibuang ke sungai menimbulkan pencemaran di muara sungai, yakni di pesisir pantai utara Jawa Tengah. Studi ini bertujuan untuk menentukan besarnya konsentrasi pencemar yang masuk ke sedimen di muara Sungai Comal dan Sungai Garang. Konsentrasi pencemaran di sungai dianalisis menggunakan software QUAL2Kw yang kemudian hasilnya akan menjadi input untuk analisis di sedimen pesisir menggunakan software MIKE 21 ECOLab. Hasil studi menyatakan bahwa Muara Comal memiliki konsentrasi BOD 4,26 mg/L pada musim barat dan 4,21 mg/L pada musim timur. Sementara Muara Garang memiliki konsentrasi BOD 18,21 mg/L pada musim barat dan 4,73 mg/L pada musim timur.
\end{abstract}

Kata Kunci: MIKE 21 ECOLab, pencemaran air, model pencemaran pesisir

\section{PENDAHULUAN}

Wilayah perairan pesisir dewasa ini kualitasnya sangat mengkhawatirkan disebabkan banyaknya pencemaran yang terjadi. Menurut National Oceanic and Atmospheric Administration (NOAA) di dalam Vikas dan Dwarakish (2015), pencemaran air di wilayah lautan sebagian besar berasal dari daratan, dan pada umumnya sumber terbesarnya berasal dari sumber pencemar non-point. Sumber pencemar non-point yang paling umum adalah dari limbah domestik, sementara sumber pencemar point atau titik adalah limbah industri. Efek akumulasi pencemaran di pantai yang terjadi jika dibebani limbah industri setiap harinya akan menimbulkan dampak yang fatal bagi biota pesisir. 
Senyawa organik yang dibawa sungai dari daratan bisa menjadi penyebab utama terjadinya eutrofikasi yang akan mampu menghancurkan ekosistem akuatik di sekitar pesisir (FAO, 2010).

Provinsi Jawa Tengah memiliki beberapa muara sungai, di antaranya adalah muara Comal dan muara Garang. Muara Comal berada pada wilayah administrasi Pemalang, Garang pada wilayah administrasi Semarang. Kedua wilayah tersebut memiliki kepadatan penduduk yang tinggi di Jawa Tengah yang berkorelasi pula dengan tingginya buangan limbah yang dihasilkan oleh para penduduk. Dengan belum tersedianya pengolahan air limbah yang terpadu di Semarang maka kedua sungai besar di Semarang, Kanal Banjir Barat dan Kanal Banjir Timur pasti mengalirkan air yang tercemar, baik oleh limbah domestik maupun limbah industri dari Kota Semarang dan Ungaran (Pramudyanto, 2014). Begitu pula di Pemalang yang belum terdapat pengolahan air limbah yang terpadu, khususnya untuk limbah domestik.

Penanganan pencemaran air memerlukan pengelolaan sumber daya air yang terpadu (terintegrasi). Salah satu langkah untuk melakukan pengelolaan sumber daya air yang terpadu adalah dengan melakukan analisis terhadap beban pencemaran yang terjadi. Kajian ini akan memberikan informasi kontribusi beban pencemaran sungai-sungai yang bermuara di perairan pantai utara Jawa bagian tengah dan timur. Informasi dari keluaran kajian ini diharapkan akan menjadi acuan yang baik untuk menetapkan kebijakan pengendalian pencemaran air di pesisir pantai utara (pantura) Jawa.

Tujuan yang hendak dicapai dari studi ini adalah:

1. Menentukan tingkat pencemaran badan air di muara sungai sepanjang pantai utara Jawa Tengah.

2. Mengidentifikasi sumber-sumber pencemar baik yang berupa point source maupun yang berupa non-point source di sepanjang DAS Jratunseluna dan DAS Pemali-Comal yang mempengaruhi kualitas air di muara sungai pantai utara Jawa Tengah.

3. Mengetahui sebaran dan konsentrasi sedimen dan bahan pencemar di perairan sekitar Muara Comal dan Garang

\section{METODE PENELITIAN}

\subsection{Kerangka Penelitian}

Tujuan utama penelitian ini adalah mendapatkan nilai konsentrasi dan sebaran parameter pencemaran di pesisir pantai utara Jawa Tengah. Beban pencemaran di sungai akan dihitung menggunakan metode kesetimbangan massa dan model QUAL2Kw. Setelah beban pencemar sungai di hilir sungai diketahui, selanjutnya dilakukan analisis sebaran konsentrasi parameter pencemar di pesisir pantai dengan cara menganalisis kualitas sedimen menggunakan model yang diperoleh dari program MIKE21 Eco Lab. Model MIKE21 telah sering digunakan dalam analisis 
kualitas air yang melibatkan model hidrodinamika dan persamaan fisika, kimia, maupun biologis yang terintegrasi. Hasil model MIKE21 dapat menentukan kelebihan kadar nutrien dan senyawa organik pada air (Panda dkk., 2015). Selain itu, Xu dkk. (2012) juga telah menggunakan MIKE21 untuk membuat simulasi kejadian eutrofikasi pada suatu waduk di Cina utara.

Kerangka dari studi ini secara umum diilustrasikan pada Gambar 1. Lokasi kajian meliputi sungai yang memenuhi kriteria berikut: 1) bermuara di Laut Jawa (pantai utara) di Provinsi Jawa Tengah; dan 2) memiliki data yang cukup reliabel. Pada saat penelitian ini dilaksanakan hanya terdapat dua sungai yang datanya cukup reliabel, yakni Sungai Comal (Kabupaten Pemalang) dan Sungai Garang (Kota Semarang).

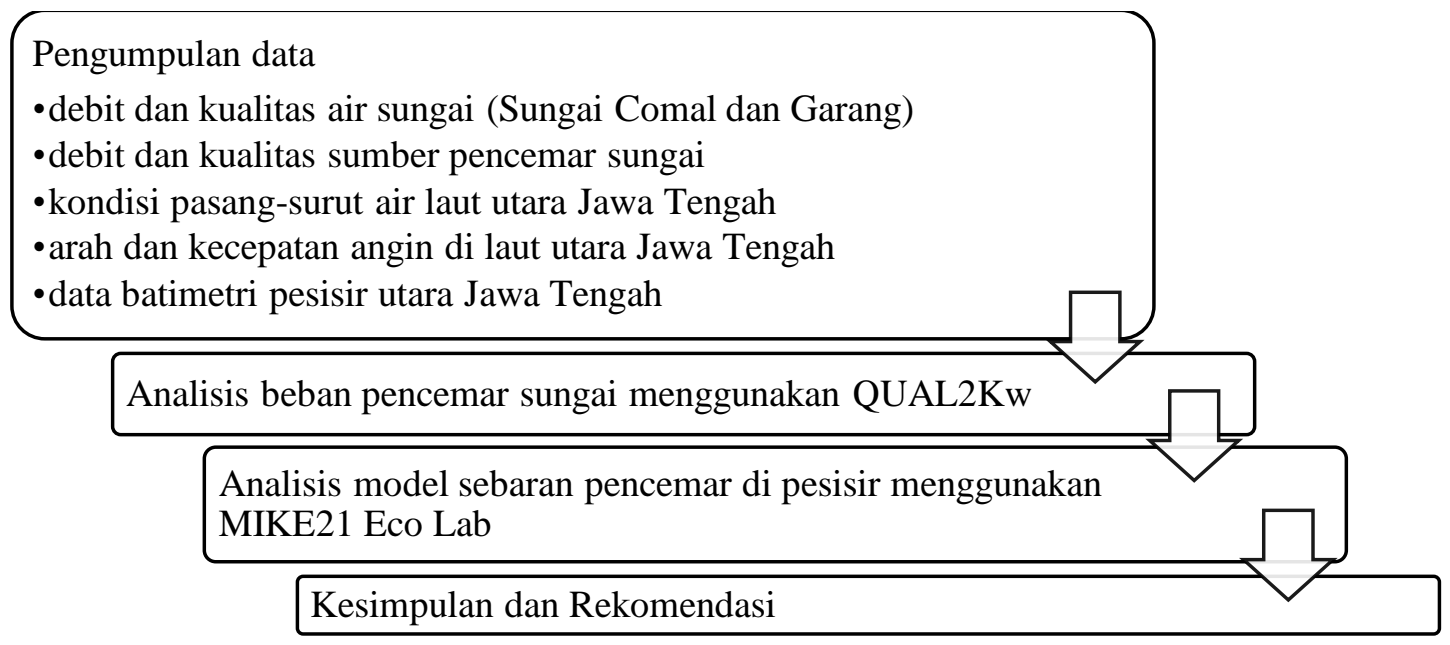

Gambar 1. Kerangka Penelitian

\subsection{Data dan Parameter}

Data yang perlu dikumpulkan untuk melakukan penelitian ini adalah 1) data air sungai (debit dan kualitas), 2) data sumber pencemar (debit dan kualitas), 3) data pasang surut air laut, 4) arah dan kecepatan angin di laut, dan 5) data batimetri (kedalaman dasar laut). Parameter kualitas air dibatasi pada parameter $\mathrm{DO}, \mathrm{BOD}, \mathrm{TSS}, \mathrm{NO}_{3}$, dan $\mathrm{PO}_{4}$. Sehingga kelima parameter tersebut yang akan dijadikan parameter kualitas air, baik di sungai mauapun laut. Data kualitas air sungai dan sumber pencemar didapatkan dari berbagai instansi (dokumen SLHD, Balai Wilayah Sungai) dan literatur penelitian terdahulu. Data arah dan kecepatan angin didapatkan dari Badan Meteorologi Geofisika dan Klimatologi (BMKG) Semarang. Data pasang surut air laut didapatkan dengan menganalisis kondisi di laut menggunakan peramalan NAOTIDE dengan menghitung Formzhal Number (FN). Sementara itu data batimetri didapatkan dari instansi terkait (KKP, Dishidros AL dan BIG). Sedimen di laut juga ikut diambil sampelnya dan diuji di laboratorium untuk mengetahui 
konsentrasi pencemar di pesisir. Nantinya data primer ini akan dijadikan pembanding dengan hasil dari model MIKE21 Eco Lab.

Tabel 1. Data Kualitas Air Sungai Comal dan Sungai Garang

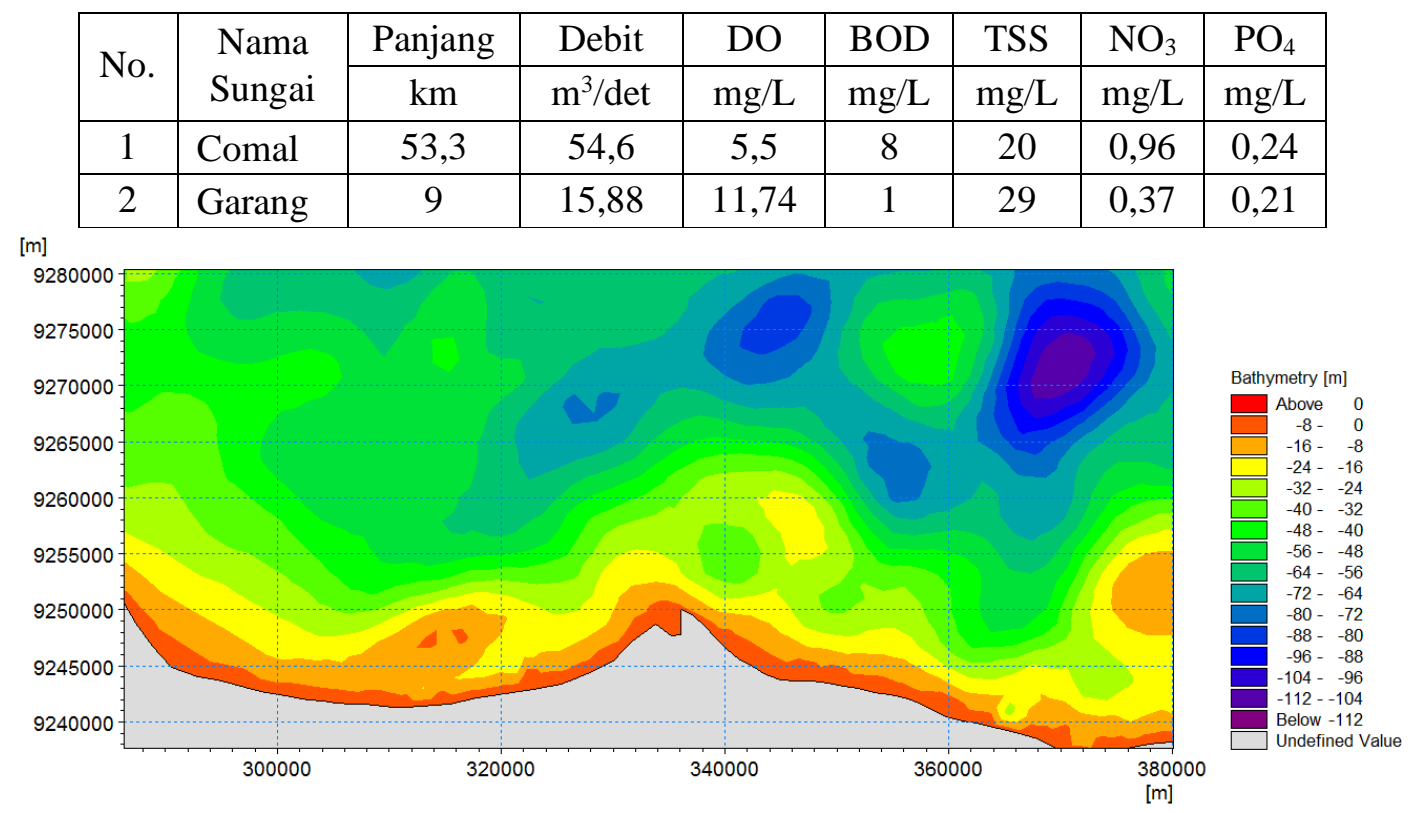

Gambar 2. Batimetri Pesisir dari Muara Sungai Comal Hasil Konversi MIKE21

\subsection{Pemodelan Kualitas Air Sungai}

Analisis yang dilakukan dalam kajian ini adalah perhitungan beban pencemaran. Beban pencemaran didapatkan dari hasil perkalian debit dan konsentrasi pencemar. Dalam analisis ini program freeware QUAL2Kw digunakan untuk membantu memperkirakan beban di muara sungai. QUAL2KW adalah software yang diprogram untuk melakukan simulasi kualitas air di sungai dengan menggunakan pendekatan aliran satu dimensi dengan pola tunak (steady). QUAL2Kw dapat membuat model kualitas air sungai yang reliabel dengan memasukkan data kualitas air di hulu sebagai input dasar dan disertai oleh input debit dan kualitas air yang masuk sebagai sumber pencemar sungai. Beban pencemar dihitung dari output QUAL2Kw yang berupa konsentrasi pencemar dan debit masukan air limbah. Beban pencemar ditentukan dengan memperhitungkan debit sungai dan konsentrasi pencemar pada muara, yakni dengan persamaan (1) berikut.

$$
\mathrm{BP}=\mathrm{Q} \times \mathrm{Ci} \times(1 \times 10-6 \times 30 \times 24 \times 3600)
$$

dengan:

BP : Beban pencemar yang berasal dari suatu sumber (ton/bulan)

Q : Debit sungai yang masuk ke perairan $\left(\mathrm{m}^{3} /\right.$ detik)

$\mathrm{Ci} \quad$ : Konsentrasi parameter ke-i (mg/L). 


\subsection{Pemodelan Sebaran Pencemar di Pesisir}

MIKE21 Ecolab digunakan untuk mensimulasikan sebaran parameter kimia yang merupakan indikator kualitas perairan di perairan Jawa Tengah. Dari pemodelan MIKE21 EcoLab, dapat diperoleh informasi pola dan kecepatan arus serta sebaran parameter TSS, DO, BOD, Fosfat, Nitrat dan Amonia pada daerah studi. MIKE21 ECOLab menggunakan persamaan (2). Sementara itu, persamaan (3) digunakan untuk menghitung perpindahan pencemar (polutant transport).

$$
\begin{aligned}
\frac{\partial c}{\partial t}+u \frac{\partial c}{\partial x}+v \frac{\partial c}{\partial y}+w \frac{\partial c}{\partial z} & =D_{x} \frac{\partial^{2} c}{\partial z^{2}}+D_{y} \frac{\partial^{2} c}{\partial z^{2}}+D_{z} \frac{\partial^{2} c}{\partial z^{2}}+S_{c}+P_{c} \\
\frac{\partial c}{\partial t} & =A D_{c}+P_{c}
\end{aligned}
$$

dengan:

c : konsentrasi variabel ECOLab

$\mathrm{u}, \mathrm{v}, \mathrm{w} \quad$ : komponen arus

Dx, Dy, Dz : koefisien dispersi

Sc $\quad$ : komponen source dan sink

Pc $\quad:$ proses ECOLab

ADc : perubahan konsentrasi karena efek adveksi dan dispersi

\section{HASIL DAN PEMBAHASAN}

\subsection{Beban Pencemar yang Masuk ke Muara}

Beban pencemaran yang masuk ke muara ditunjukkan oleh analisis hasil pemodelan QUAL2Kw. Nilai beban pencemaran tersebut ditunjukkan oleh Tabel 2. Hasil pemodelan yang berupa konsentrasi parameter kualitas pencemar di sungai kemudian dimasukkan sebagai input model MIKE21. Kondisi awal pada model MIKE21 menggunakan asumsi bahwa perairan dalam kondisi yang baik, dengan nilai parameter yang dimodelkan berada pada kondisi alami yang ada pada laut yang bersih seperti disajikan pada Tabel 2 .

Tabel 2. Beban Pencemar yang Masuk ke Muara

\begin{tabular}{|c|c|c|c|c|c|c|}
\hline \multirow{2}{*}{ No. } & \multirow{2}{*}{$\begin{array}{c}\text { Nama } \\
\text { Sungai }\end{array}$} & Debit & $\mathrm{BOD}$ & $\mathrm{TSS}$ & $\mathrm{NO}_{3}$ & $\mathrm{PO}_{4}$ \\
\cline { 3 - 7 } & $\mathrm{m}^{3} / \mathrm{detik}$ & ton/hari & ton/hari & ton/hari & ton/hari \\
\hline 1 & Comal & 54,6 & 2,50 & 78,03 & 38,14 & 10,78 \\
\hline 2 & Garang & 189,94 & 379,58 & 48,58 & 64,82 & 27,90 \\
\hline
\end{tabular}




\subsection{Pemodelan Arus Laut di Pesisir Muara}

Mula-mula dilakukan pemodelan arus terlebih dahulu pada MIKE21. Arus pada pemodelan MIKE21 merupakan parameter kunci sebaran parameter kimia air karena bahan kimia yang masuk dari sungai ke laut dibawa oleh arus. Elevasi muka air laut akibat pasang surut sangat penting untuk diketahui. Informasi pasang surut digunakan sebagai input data untuk model pola arus dan transport sedimen. Pada studi ini, arus pada MIKE21 dihasilkan dengan menyelesaikan persamaan kontinuitas dari parameter kedalaman perairan serta dua parameter penggerak utama yaitu pasangsurut dan angin. Berdasarkan data pengamatan, dilakukan analisis pasang surut untuk menghitung amplitudo dan beda fasa 9 konstanta pasang surut. Dalam analisis ini digunakan metode analisis pemisahan komponen metode Least Square. Sembilan konstanta utama pasang surut adalah:

M2 : Komponen utama bulan (semi diurnal)

S2 : Komponen utama matahari (semi diurnal)

N2 : Komponen eliptis bulan

K2 : Komponen bulan

K1 : Komponen bulan

O1 : Komponen utama bulan (diurnal)

P1 : Komponen utama matahari (diurnal)

M4 : Komponen utama bulan (kuarter diurnal)

MS4 : Komponen matahari bulan

Tabel 3. Konstanta Pasang Surut Pesisir Muara Sungai Comal

\begin{tabular}{|c|c|c|c|c|c|c|c|c|}
\hline & S0 & M2 & S2 & N2 & K1 & O1 & M4 & MS4 \\
\hline $\mathbf{A}(\mathbf{c m})$ & 17,663 & 10,32 & 5,21 & 2,78 & 12,43 & 9,94 & 0 & 0 \\
\hline $\mathbf{g}(\mathbf{o})$ & 0 & 111,31 & 303,19 & 70,31 & 356,1 & 24,55 & 87,44 & 186,24 \\
\hline
\end{tabular}

Tabel 4. Konstanta Pasang Surut Pesisir Muara Sungai Garang

\begin{tabular}{|c|c|c|c|c|c|c|c|c|}
\hline & S0 & M2 & S2 & N2 & K1 & O1 & M4 & MS4 \\
\hline $\mathbf{A ~ ( c m ) ~}$ & 10,813 & 4,81 & 4,52 & 1,33 & 30,41 & 12,4 & 0 & 0 \\
\hline $\mathbf{g}(\mathbf{o})$ & 0 & 11,93 & 268,67 & 337,12 & 227,55 & 147,62 & 289,7 & 164,23 \\
\hline
\end{tabular}

Setelah konstanta pasang surut diketahui, tipe pasang surut dapat didefinisikan berdasarkan rumus Formzhal Number (FN) sebagai berikut :

$$
F=\frac{A\left(K_{1}\right)+A\left(O_{1}\right)}{A\left(M_{2}\right)+A\left(S_{2}\right)}
$$


Dari persamaan Formzhal di atas, tipe pasang surut ditentukan melalui kriteria berikut:

$\mathrm{F}=<0,25 \quad:$ tipe pasang surut harian ganda

$\mathrm{F}=0,26-1,50:$ tipe pasang surut campuran condong ke harian ganda

$\mathrm{F}=1,50-3,00: \quad$ tipe pasang surut campuran condong ke harian tunggal

$\mathrm{F}=>3,00 \quad: \quad$ tipe pasang surut harian tunggal

Berdasarkan perhitungan, tipe pasang surut di area muara Sungai Garang adalah harian tunggal (Diurnal Tide), dimana terjadi hanya 1 kali pasang dan 1 kali surut. Sementara tipe pasang surut di area muara Sungai Comal memiliki tipe pasang surut campuran, cenderung pada pasang surut ganda (Mixed Semi Diurnal Dominant Tide), dimana dalam satu hari terjadi dua kali pasang dan dua kali air surut dengan ketinggian yang berbeda.

\subsection{Pemodelan Sebaran Kontaminan di Pesisir}

Kondisi awal pada model MIKE21 menggunakan asumsi bahwa perairan dalam kondisi yang baik, dengan nilai parameter yang dimodelkan berada pada kondisi alami seperti yang ditunjukkan oleh Tabel 6. Setelah parameter kondisi awal model ditentukan, hasil pemodelan numerik arus pada angin musim barat dan angin musim timur di pesisir muara kemudian digabung dengan data kualitas air yang masuk ke pesisir sehingga didapat model sebaran konsentrasi pencemar.

Tabel 6. Parameter Kondisi Awal Model MIKE21

\begin{tabular}{|c|c|l|}
\hline Parameter & Nilai & \multicolumn{1}{|c|}{ Referensi } \\
\hline BOD & 9 & Salmin (2005) \\
\hline DO & 5,45 & Sanusi (2004) \\
\hline Fosfat & 0,004 & Edward dan M.S. Tarigan (2003) \\
\hline Nitrat & 0,05 & Edward dan M.S. Tarigan (2003) \\
\hline Ammonia & 0,1 & Andhika (2013) \\
\hline
\end{tabular}

Hasil pemodelan sebaran konsentrasi TSS (Total Suspended Solid) di muara Comal diperlihatkan oleh Gambar 3 (pada angin musim barat) dan Gambar 4 (pada angin musim timur). TSS merupakan residu dari padatan total yang tertahan oleh saringan dengan ukuran partikel maksimal $2 \mu \mathrm{m}$ atau lebih besar dari ukuran partikel koloid. TSS umumnya dihilangkan dari air dengan flokulasi dan penyaringan. Nilai TSS umumnya semakin rendah ke arah laut. Hal ini disebabkan padatan tersuspensi tersebut disuplai oleh daratan melalui aliran sungai. Hasil pemodelan menunjukkan bahwa kandungan TSS pada lokasi studi berada pada kisaran yang sama untuk musim Barat dan musim Timur, yaitu dibawah $0,14 \mathrm{mg} / \mathrm{L}$. Dari hasil pemodelan, bahwa TSS lebih terkonsentrasi pada daerah muara, hal ini dikarenakan bahwa debit dan kecepatan tersebut, maka disimpulkan perairan Comal mempunyai kandungan TSS yang rendah, di bawah baku mutu. 


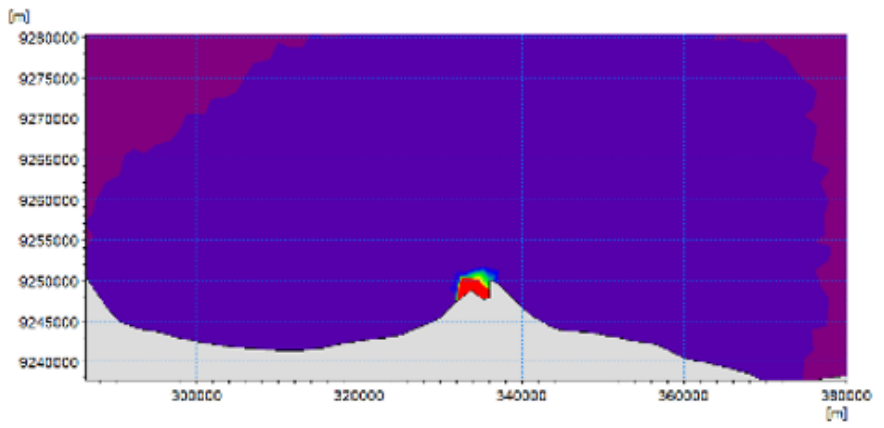

TSS Pasang Comal

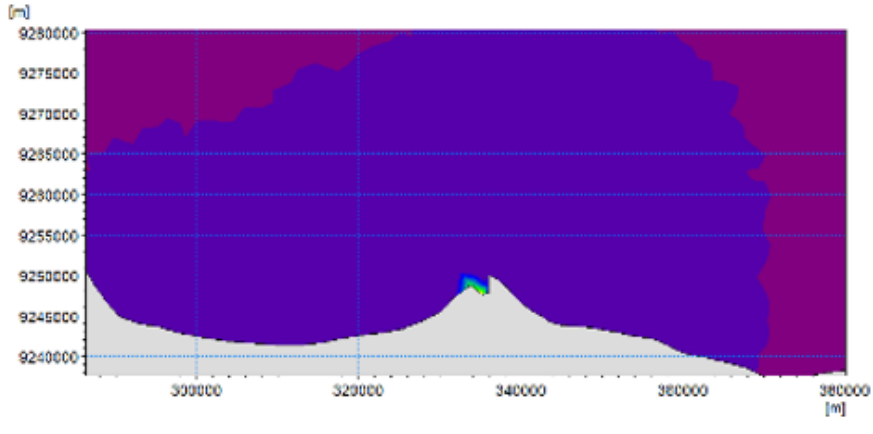

TSS Surut Comal

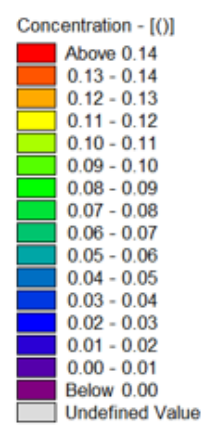

Concentration - [0] Above 0.14 $0.13-0.14$ $0.12-0.13$ $0.10-0.11$ $0.09-0.10$ $0.08-0.09$ $0.07-0.08$ $0.06-0.07$ $0.04-0.05$ $0.03-0.04$ $0.02-0.03$ $0.01-0.02$ $0.00-0.01$ Below 0.00 Undefined Value

Gambar 3. Model Sebaran Konsentrasi TSS pada Arus Pasang di Muara Comal

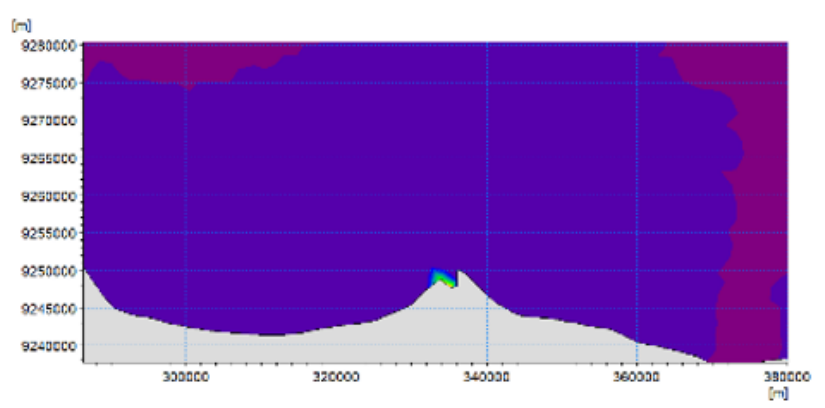

TSS Pasang Comal

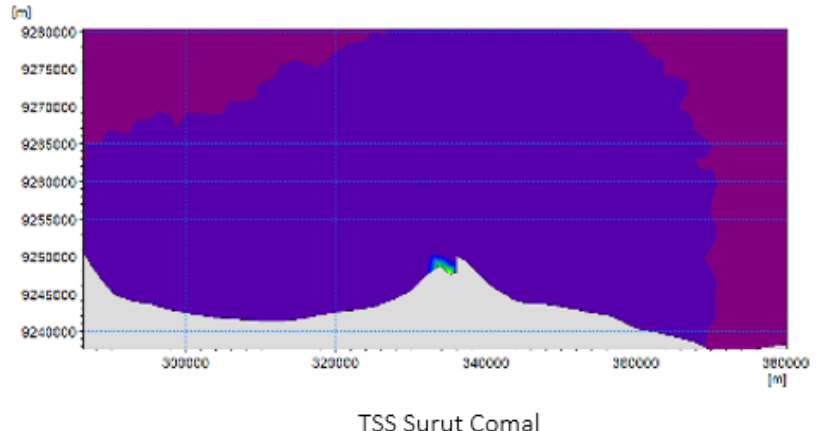

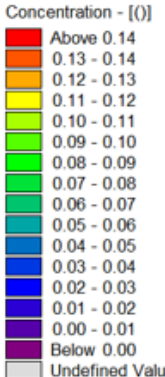

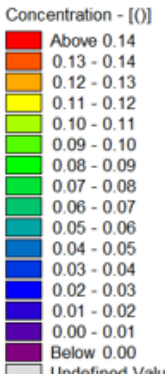

Gambar 4. Model Sebaran Konsentrasi TSS pada Arus Surut di Muara Comal 
Hasil pemodelan sebaran konsentrasi BOD ditampilkan oleh Gambar 5 (pada angin musim timur) dan Gambar 6 (pada angin musim timur). Hasil pemodelan MIKE21 menunjukkan bahwa kandungan BOD pada lokasi studi berada pada kisaran 2,4 sampai 2,8 mg/L pada angin musim barat. Pada angin musim timur sebaran BOD lebih kecil dibandingkan pada angin musim barat dengan konsentrasi BOD yang lebih tinggi. Hal ini disebabkan oleh perbedaan kecepatan arus, dimana kecepatan arus pada angin musim barat lebih tinggi dibanding arus pada angin musim timur, sehingga BOD lebih tersebar dan menurun konsentrasinya.

Hasil pemodelan parameter Fosfat pada muara Comal menunjukkan bahwa sebaran Fosfat berada pada kisaran 1,4 mg/L pada angin musim barat dan berada pada kisaran 1,1 mg/L pada angin musim timur. Tingginya konsentrasi fosfat ketika terjadi angin musim barat dimungkinkan oleh limpasan nutrien fosfat dari darat dan sungai yang lebih tinggi karena adanya aktivitas pertanian yang lebih intensif di di musim hujan. Santoso (2007) pada kajiannya juga menyatakan bahwa tingginya konsentrasi fosfat disebabkan oleh limpasan nutrien fosfat dari daratan termasuk dari sungai, terlebih jika curah hujan daerah tersebut cukup tinggi.
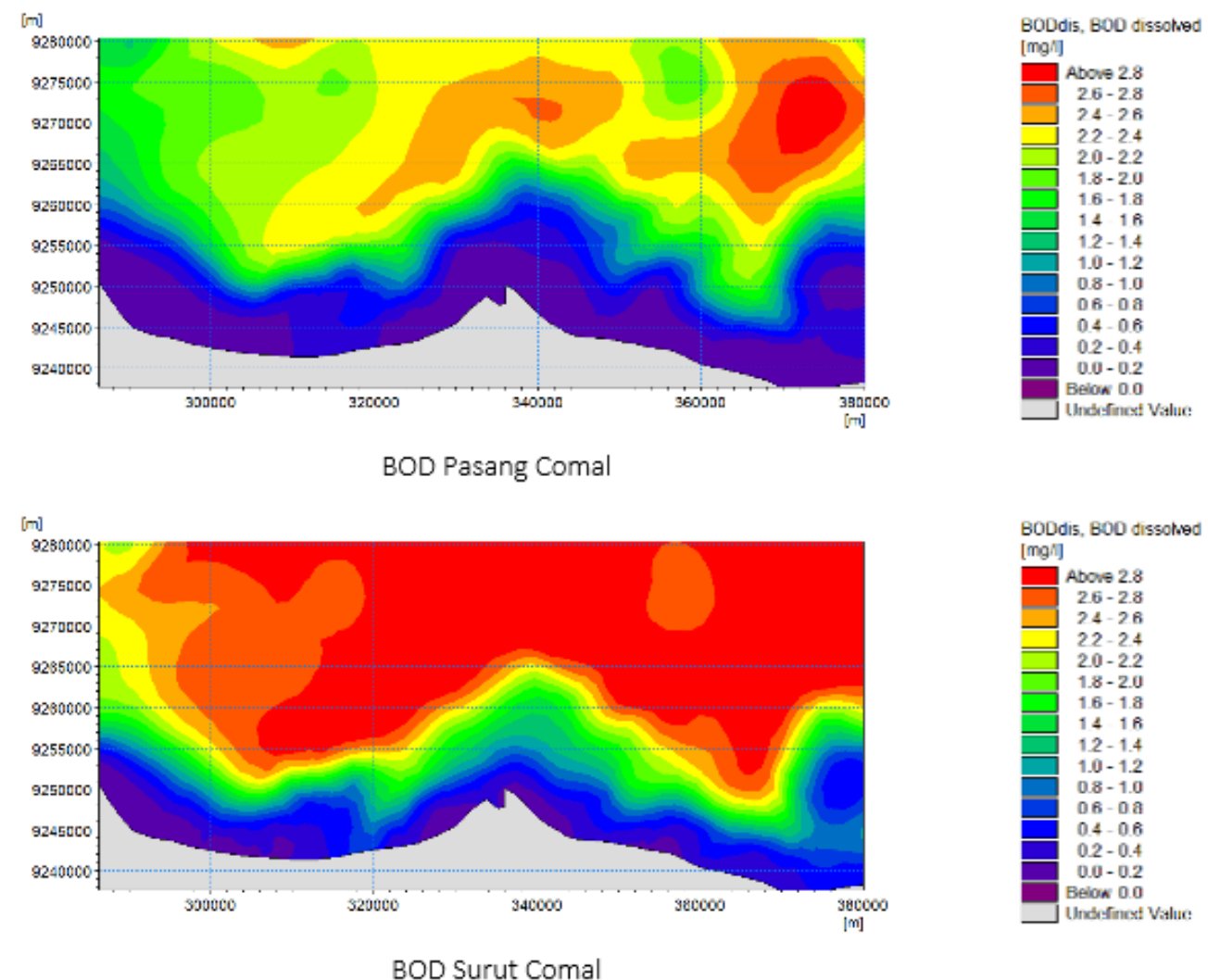

Gambar 5. Model Sebaran Konsentrasi BOD pada Angin Musim barat di Muara Comal 

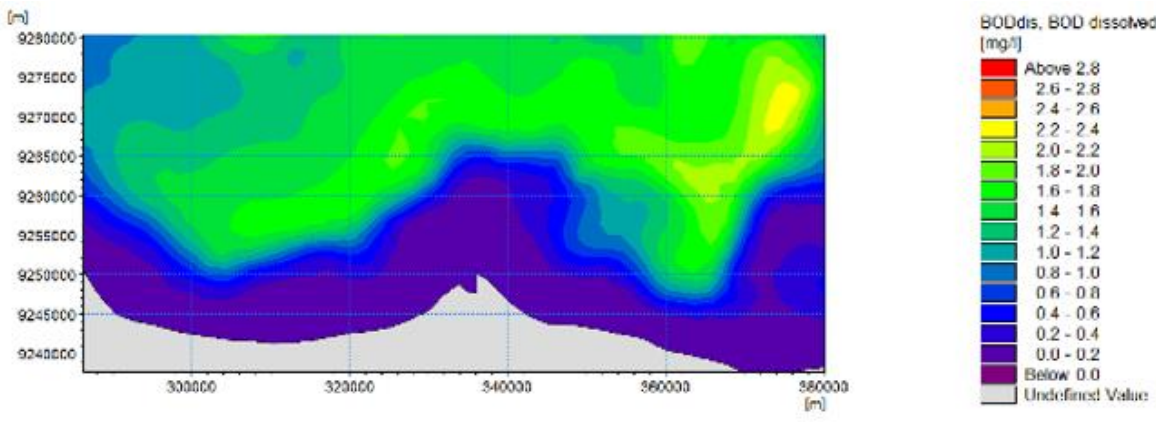

BOD Pasang Comal
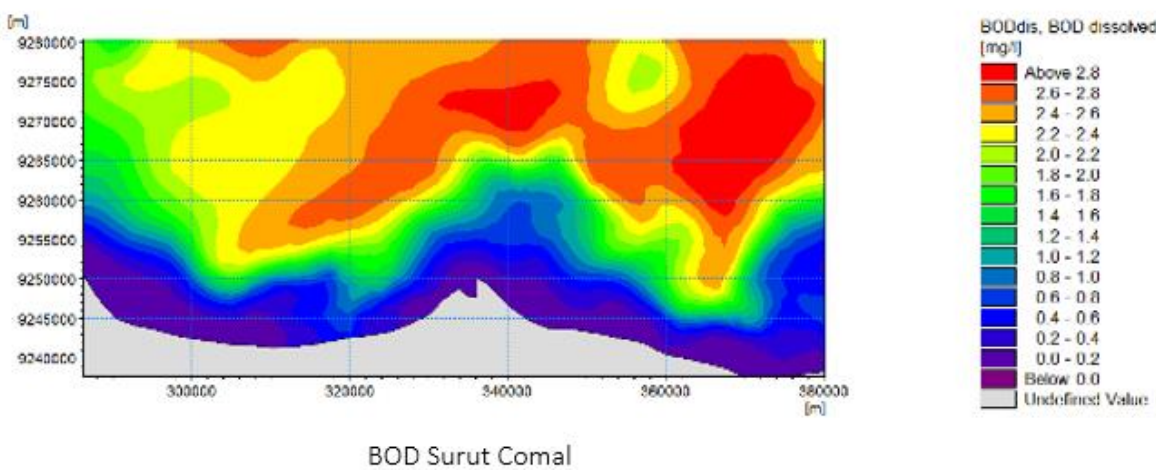

Gambar 6. Model Sebaran Konsentrasi BOD pada Angin Musim Timur di Muara Comal

Sementara itu, hasil pemodelan parameter Nitrat pada muara Comal menunjukkan konsentrasi sekitar 0,09 sampai $0,23 \mathrm{mg} / \mathrm{L}$ pada saat angin musim timur dan 0,01 hingga $0,15 \mathrm{mg} / \mathrm{L}$ pada saat angin musim barat. Kandungan nitrat pada muara Comal cukup tinggi yang mungkin disebabkan oleh aktivitas tambak di sekitar muara Sungai Comal. Yoo dan Boyd (1994) menyatakan bahwa adanya aktivitas pertambakan juga dapat memberikan kontribusi bahan organik yang banyak mengandung senyawa nitrat.

Secara umum, hasil pemodelan dengan MIKE21 menunjukkan kecenderungan hasil yang underestimate dibandingkan kondisi lingkungan sebenarnya. Hal ini ditunjukkan dengan hasil nilai yang lebih rendah pada semua parameter kualitas pencemar air. Kecenderungan underestimate ini dimungkinkan terjadi sebab nilai masukan model hanya berasal dari muara sungai besar saja. Padahal pada kondisi sebenarnya terdapat masukan beban limbah dari sungai kecil atau pesisir pantai. Meskipun begitu, hasil pemodelan menunjukkan selisih yang tidak jauh berbeda antara hasil simulasi dan pengukuran lapangan. 


\section{KESIMPULAN DAN SARAN}

Hasil dari kajian ini menemukan bahwa konsentrasi keluaran dari model menggunakan program MIKE 21 ECOLab pada masing-masing muara sungai adalah sebagai berikut:

a. Sungai Comal memiliki konsentrasi TSS sekitar $6,75 \times 10^{-7} \mathrm{mg} / \mathrm{L}$ pada angin musim barat, dan sekitar 4,68_ $\times 10^{-8} \mathrm{mg} / \mathrm{L}$ pada angin musim timur. Konsentrasi BOD yang tersebar sekitar 4,26 $\mathrm{mg} / \mathrm{L}$ pada saat angin musim barat dan sekitar $4,21 \mathrm{mg} / \mathrm{L}$ pada saat angin musim timur. Konsentrasi nitrat berkisar di sekitar $0,322 \mathrm{mg} / \mathrm{L}$ saat angin musim barat dan 0,333 $\mathrm{mg} / \mathrm{L}$ saat angin musim timur. Konsentrasi fosfat berkisar sekitar $0,455 \mathrm{mg} / \mathrm{L}$ saat angin musim barat dan $0,388 \mathrm{mg} / \mathrm{L}$ saat angin musim timur.

b. Sungai Garang memiliki konsentrasi TSS sekitar $0,134 \mathrm{mg} / \mathrm{L}$ pada angin musim barat dan 0,014 $\mathrm{mg} / \mathrm{L}$ pada angin musim timur. Konsentrasi BOD yang tersebar sekitar 18,21 mg/L saat angin musim barat dan 4,73 mg/L saat angin musim timur. Konsentrasi nitrat berkisar di sekitar 2,98 $\mathrm{mg} / \mathrm{L}$ saat angin musim barat dan $0,767 \mathrm{mg} / \mathrm{L}$ saat angin musim timur. Konsentrasi fosfat berkisar sekitar $1,82 \mathrm{mg} / \mathrm{L}$ saat angin musim barat dan $0,755 \mathrm{mg} / \mathrm{L}$ saat angin musim timur.

Saran dari hasil studi ini adalah perlunya pengendalian beban pencemaran yang terjadi di daratan dengan melakukan kerja sama antar Kementerian Kelautan dan Perikanan dengan Kementerian Lingkungan Hidup. Selain itu, mengingat belum optimalnya ketersediaan data konsentrasi pencemar hasil pemantauan di laut secara time series, maka perlu adanya pembangunan database kualitas parameter pencemar dengan membangun stasiun pemantau di beberapa titik pantai utara. Selain di wilayah pantai, dirasa perlu juga untuk melakukan penambahan titik pemantau kualitas air di daratan, yakni di titik-titik tertentu dekat sumber pencemar sepanjang Sungai Garang dan Sungai Comal.

\section{DAFTAR PUSTAKA}

Andhika, G.R., (2013), Pengaruh pH Terhadap Perairan dan Organisme Perairan. Fakultas Perikanan dan Ilmu Kelautan ( FPIK ) Universitas Padjajaran.

Edward dan Tarigan, M.S., (2003), Pengaruh Musim Terhadap Fluktuasi Kadar Fosfat dan Nitrat di Laut Banda, Jurnal Makara, Sains, Vol.7, No.2, hal.82-89.

FAO, (2010), The potential of spatial planning tools to support the ecosystem approach to aquaculture, FAO Fisheries and Aquaculture Proceedings 17. 
Panda, U.S., Mahanty, M.M., Rao, V.R., Patra, S., dan Mishra, P., (2015), Hydrodynamics and Water Quality in Chilika Lagoon - A Modelling Approach, 8th International Conference on Asian and Pacific Coasts (APAC 2015), Jurnal Procedia Engineering No.116, hal. 639-646.

Pramudyanto, B., (2014), Pengendalian Pencemaran dan Kerusakan di Wilayah Pesisir, Jurnal Lingkar Widyaiswara, Vol.1, No.4, hal.21-40.

Salmin, (2005), Oksigen Terlarut (DO) dan Kebutuhan Oksigen Biologi (BOD) sebagai Salah Satu Indikator untuk Menentukan Kualitas Perairan. Jurnal Oseana, Vol.30, No.3, hal.21-26.

Santoso, A.D., (2007), Kandungan Zat Hara Fosfat pada Musim Barat dan Musim Timur di Teluk Hurun Lampung. Jurnal Teknologi Lingkungan, Vol.8, No.3, hal.207-210.

Sanusi, H. S., (2004), Karakteristik Kimiawi dan Kesuburan Perairan Teluk Pelabuhan Ratu pada Musim Barat dan Timur, Jurnal Ilmu-Ilmu Perairan dan Perikanan Indonesia, Vol.11, No.2, hal.93-100.

Vikas, M., dan Dwarakish, G.S. (2015), Coastal Pollution: A Review. Aquatic Procedia: International Conference on Water Resources, Coastal and Ocean Engineering (ICWRCOE 2015).

Xu, M.J, Yu, L., Zhao, Y.W., dan Li, M. (2012), The Simulation of Shallow Reservoir Euthrophication Based on MIKE21: a Case Study of Douhe Reservoir in North China. The 18th Biennial Conference of the International Society for Ecological Modelling. Procedia Environmental Sciences No.13, hal.1975-1988.

Yoo, K.H. dan Boyd, C.E., (1994), Hydrology and Water Supply for Pound Aquaculture, Chapman and Hill, New York. 